\title{
ACCEPTED
}

\section{Katie Barclay}

Marginal households and their emotions: the 'kept mistress' in enlightenment Edinburgh, in Spaces for feeling: Emotions and sociabilities in Britain, 1650-1850, 2015 / Broomhall, S. (ed./s), pp.95-111

(C) 2015 individual chapters, the contibutors

http://dx.doi.org/10.4324/9781315732145

\section{PERMISSIONS}

https:/www.routledge.com/info/open access/by the chapter

\section{2) Archiving of a chapter on a website or in a repository. (The 'Green' OA Model).}

Green open access refers to self-archiving of a chapter and often applies to earlier versions of the chapter.

Chapters from all our books are eligible for green open access.

Each individual author or contributor can also choose to upload one chapter from the 'Accepted Manuscript' (AM). An AM is typically the post-contract but pre-production (i.e. not copy -edited, proofread or typeset) Word Document/PDF of the chapter. Authors may upload the AM chapter to a personal or departmental website immediately after publication of the book - this includes posting to Facebook, Google groups, and LinkedIn, and linking from Twitter. Authors can also post the AM book chapter to an institutional or subject repository or to academic social networks like Mendeley, ResearchGate, or Academia.edu after an embargo period of 18 months for Humanities and Social Sciences books or 12 months for STEM books.

Authors may not post the final published book chapter to any site, unless it has been published as gold open access on our website.

To encourage citation of an author's work we recommend that authors insert a link from their posted AM to the published book on the Taylor \& Francis website with the following text: "This is an Accepted Manuscript of a book chapter published by Routledge/CRC Press in [BOOK TITLE] on [date of publication], available online: http://www.routledge.com/[BOOK ISBN URL] or "http://www.crcpress.com/[BOOK ISBN URL]"

\section{September 2018}




\section{Marginal Households and their Emotions}

\section{The “Kept Mistress” in Enlightenment Edinburgh}

\section{Katie Barclay}

Why do you ask me about my relations. Don't you know that I have non, when I become your whore I lost all and every thing that was previous to me, an outcast from society, sad and solitary, has the best time of life past and every year gains me a few more enemies but not one friend - what else can a Homeless Vagabond expect (Mary Hutton to Gilbert Innes, 7 January 1822, underline in original). ${ }^{1}$

In 1814 at age twenty-seven, Mary Hutton met sixty-three-year-old Gilbert Innes of Stowe in the grounds of St Andrew’s Church, Edinburgh, as she ran an errand. Innes was a central figure in Edinburgh society: the Deputy Governor of the Royal Bank of Scotland, a Director of the Assembly Rooms and the Society of Antiquaries, a major patron of the arts and extremely wealthy. ${ }^{2}$ Hutton was one of several sisters from a middling Edinburgh family, supplementing her income from her father with work as a governess when she met Gilbert. They formed an intimacy that lasted over a decade, maintained in part by a regular correspondence from Hutton that survives in the Innes of Stowe archive. ${ }^{3}$ Innes financially

\footnotetext{
${ }^{1}$ National Records of Scotland [hereafter NRS], GD113/5/481/151, MP [Mary Hutton] to Gilbert Innes, 7 January 1822.

${ }^{2}$ A brief biography is available here: “Gilbert Innes,” Royal Bank of Scotland Heritage Hub, accessed February 20, 2014, http://heritagearchives.rbs.com/people/list/gilbert-innes.html; a fuller account of Innes’ life can be found in Katie Barclay, "Illicit Intimacies: the Many Homes of Gilbert Innes of Stowe (1751-1832),” Working Paper.

${ }^{3}$ The Innes of Stowe archive is found at the National Records of Scotland under GD113 Innes of Stowe. Innes’ personal correspondence is collated chronologically and letters by Hutton and his other mistresses are found throughout.
} 
supported Hutton as one of several mistresses; Hutton in return provided sexual services, but also affection and emotional support.

In many respects, this relationship was devastating for Hutton, although the consequences were not immediately obvious. On the one hand, her correspondence indicates that she loved Innes and was sustained by both his finances and his, not always unwaivering, affection. Yet, on the other, when their relationship was exposed around 1819, she was shunned by her family and forced to move from her lodgings in Edinburgh. In losing "her character," she also lost the ability to earn in her profession as governess, a role that required particular moral probity. Over the next decade, she lived on the margins of Edinburgh society. Her relationship with her family was, at best, strained and eventually broke down entirely; she was disinherited; she was forced to leave the part of Edinburgh where she was known and had an established community, and she subsequently moved several times each year for the next decade as her relentlessly nosey landladies and neighbours became aware that she was a "kept mistress.” As the years past and her hopes of marrying Innes faded, Hutton became increasingly upset at the consequences of her choices and the "sad and solitary" life she lived, a distress heightened by the hardships of living on the social margins and in transitory accommodation. In this, she was not alone. Some of Gilbert's other mistresses similarly struggled with the social isolation and poverty that their lack of “respectability” entailed. The desire for a stable "home” was a central motif within their writings, signifying not just somewhere to live but emotional security, respectability and a place in society.

Studies of the socially-marginal are increasing, but have tended to focus on lives of the poor - equating marginality with poverty. Histories of courtesans and "kept mistresses" are particularly rare, usually restricted to biographies of women who were themselves 
celebrities or who were connected to well-known men. ${ }^{4}$ Works about prostitution more broadly defined are growing, but are emerging from work on institutional records that often capture the poorest and most vulnerable amongst this social group or from literary studies, that focus on representations. ${ }^{5}$ Yet, as Leah Leneman and Olwen Hufton remind us, most women who held the designation of "mistress" were not wealthy or high-profile, nor were they always desperately poor. Indeed, many were women who believed themselves to be married, before their relationships were later redesignated by the courts for legal reasons, or women who had expected marriage but found that it was not forthcoming. ${ }^{6}$ Social histories of such women, their motivations, feelings and sense of identity, are conspicuously absent. This chapter seeks to give access to the experience of one such woman, Mary Hutton, through her correspondence with Gilbert Innes, seeking to understand her place in society and its implications for both social order and her emotional world. It explores the social isolation, vulnerability and longing for home that living in marginal households caused such women, and the emotional toll of being an "outsider” in Enlightenment Edinburgh.

\footnotetext{
${ }^{4}$ For example, Frances Wilson, The Courtesan's Revenge: Harriette Wilson, the Woman who Blackmailed the King (London: Faber \& Faber, 2003); Katie Hickman, Courtesans (London: Harper Collins, 2003); Paula Byrne, Perdita: The Literary, Theatrical, and Scandalous Life of Mary Robinson (New York: Random House, 2004); Kate Williams, England's Mistress: The Infamous Life of Emma Hamilton (London: Random House, 2012).

${ }^{5}$ Laura J. Rosenthal, Infamous Commerce: Prostitution in Eighteenth-Century British Literature and Culture (Cornell: Cornell University Press, 2006); Laura J. Rosenthal, Nightwalkers: Prostitute Narratives from the
} Eighteenth Century (New York: Broadview Press, 2008); Linda Mahood, The Magdalenes: Prostitution in the Nineteenth Century (London: Routledge, 1990); Tony Henderson, Disorderly Women in Eighteenth-Century London: Prostitution and Control in the Metropolis, 1730-1830 (London: Longman, 1999).

${ }^{6}$ Olwen Hufton, The Prospect Before Her: A History of Women in Western Europe, 1500-1800 (London: HarperCollins, 1995), 303-35; Leah Leneman, “Wives and Mistresses in Eighteenth-Century Scotland,” Women’s History Review 8 (1999): 671-92. 
In what place in society Mary Hutton should be situated, and so what historiography her story contributes to, is a complex question. On the one hand, after her affair with Innes was exposed, she had no resources or occupation of her own, and was reliant on Innes' patronage for support, much like many of those who would conventionally be understood as "poor" in this society. ${ }^{7}$ This support was not always paid regularly, leaving her vulnerable to hunger and homelessness. On the other hand, Innes’ support would have been considered generous by most women from a lower-class background. However, it was not enough to support Hutton as the "respectable" middle-class woman that she was and wished to present to the world. In order to maintain this appearance, she was required to live in more expensive lodgings and maintain her clothing to a higher level than her budget allowed. This can be compared to the "genteel poverty" that many unmarried middling and elite women of the period lived in, but Mary's situation was conspicuous in her dislocation from the polite social networks and charity that acted as succour for women whose marginality was primarily financial. ${ }^{8}$ As this chapter demonstrates, her status as a "marginal” woman was not in question. For this reason, much about her lifestyle was not very different from the poor that she wished desperately to differentiate herself from.

Hutton can be compared with another of Innes’ mistresses, A. Alexander. Her first name is unknown as she never signed her letters, but the original archivist, probably Innes

\footnotetext{
${ }^{7}$ Pamela Sharpe and Joanne McEwan, “Introduction,” in Accommodating Poverty: The Housing and Living Arrangements of the English Poor, c.1600-1850, eds. Joanne McEwan and Pamela Sharpe (Basingstoke: Palgrave Macmillan, 2011), 3-4.

${ }^{8}$ Anthony James Hammerton, Emigrant Gentlewomen: Genteel Poverty and Female Migration, 1830-1914 (Canberra: Australian National University Press, 1979); Joanne McEwan and Pamela Sharpe, ““It Buys Me Freedom’: Genteel Lodging in Late-Seventeenth and Eighteenth-Century London,” Parergon 24, no. 2 (2007): 139-61; Alison Duncan, “’Old Maids’: Family and Social Relationships of Never-Married Scottish Gentlewomen, c. 1740-c.1840,” PhD Thesis, University of Glasgow, 2012.
} 
himself, wrote the name of each correspondent on the front of his thousands of surviving letters, along with the date of receipt, location of sender, and occasional remarks on content. Mary Hutton was usually signified as 'MP', which was how she signed her letters but also how Innes described her on the front page. Her 'real' name, if it was not also a pseudonym, is only found in a small number of pieces from the early years. For both women, and for many of Innes' other mistresses (thirty-two can be identified by name in his records), the decision not to use real names was a desire to ensure that Innes' “disrespectable” correspondents remained anonymous from his wider family and the Edinburgh community, in the case that the letters went astray. ${ }^{9}$

After Innes received their epistles, they were folded into small rectangles, bundled in order of receipt (rather than by correspondent) and tied with a string. Following his father's pattern, Innes appears to have kept the bulk of his personal correspondence, mixing love letters amongst those from family, associational business, begging letters requesting charity, and ephemera, such as printed invitations to support the local lying-in hospital. His replies to these do not survive, apart from a few to his sister held within her collection. There are no extant letters from Innes to his mistresses. Innes filed the personal letters he received alongside his business correspondence (which are currently separate from his personal letters), estate papers, and detailed account books of his expenditure that he kept throughout his life.

Innes died unmarried, but with a number of illegitimate children. The estate initially went to his unmarried sister, but after her death in 1839, the archive was split and a considerable part was taken by the Innes lawyers as they tried to determine whom of the many claimants on the estate had a legitimate right. Much of the personal correspondence

\footnotetext{
${ }^{9}$ For example see discussion on keeping letters secret in NRS, GD113/5/487/49, MP to Gilbert Innes, 3 May 1824.
} 
appears to have been retained by the lawyers, signified by the red numbering that was added by a Mr Cathcart during the legal suit to allow production during the trial. These letters remained in the law firm's archive until 1979, when it was added to a collection that had been held by the family and donated to the, then, Scottish Record Office in $1947 .{ }^{10}$ It is likely because they sat as legal evidence for over a century that these evidences of Innes's lifestyle survived the conservative archival impulses of the late nineteenth and early twentieth century, where so many similar records did not.

Alexander appears to have been a servant before meeting Innes, and after she became his mistress supported herself by taking in laundry and other casual work, as well as through payments from Innes that supplemented her income. Perhaps because of her social background, unlike Hutton, she never expected Innes’ payments to cover all of her living expenses, and indeed, she may have expected to work even if she had married. Alexander's relationship with Innes seems to have predated her first surviving letters in 1811 and she often alludes to the relationship’s long history, although when it began is difficult to surmise. ${ }^{11}$ Like with Hutton, it appears to have continued past 1826 when the surviving letters end. Neither of the women appears to have had children, or at least they are not mentioned in their correspondence. Innes paid support for a child of Mary Alexander born in 1791, but whether A. Alexander and Mary are the same person is unknown. ${ }^{12}$

Social background influenced how Hutton and Alexander experienced social marginality and poverty, not least in terms of how Innes treated them. ${ }^{13}$ Yet the

\footnotetext{
${ }^{10}$ A history of the provenance of these records are held as part of the estate papers, NRS, GD113.

${ }^{11}$ NRS, GD113/5/460/115, A. Alexander to Gilbert Innes [19 January 1811].

${ }^{12}$ NRS, GD113/5/282d/49, Richard Richardson to Gilbert Innes Esq, 17 August 1791; Discharge, May;

GD113/5/282d/61, Alexander to Gilbert Innes, 28 September 1791. This child was "taken charge” of by Richard Richardson.

${ }^{13}$ Barclay, "Illicit Intimacies.”
} 
correspondence of both women provides a clear sense of the isolation, loss and vulnerability that arose from their social position. Like Hutton, Alexander noted: "What have I done in my lifetime to you that you seem to shoe such revenge to me that has been a despised out cast from my own relations friendless helpless with a broken heart for your sake and yours only.” ${ }^{14}$ In this, Hutton’s story, marked by transience, insecurity and dislocation, has useful parallels with that of other marginal groups in British society.

Whilst the pre-modern British lower classes have been viewed as particularly mobile, moving across the four kingdoms for work, as vagrants, or in hope of a better life, it is also recognised that they had a strong sense of "home” or "belonging.” As Laura Gowing has demonstrated, even very poor and marginalised migrants to the English capital quickly grasped the contours of the social landscape, building networks of support and learning how to utilise local resources. ${ }^{15}$ Similarly, Tim Hitchcock has demonstrated that beggars often had a defined place within early modern social structures, recognised as members of their communities and entitled to certain types of support and acknowledgement. ${ }^{16}$ A sense of "home" was also instilled in the lower classes, and much of the rest of the population, by the poor law system in England and the parish in Scotland, where a person's place of settlement (either where they were born or which they earned through employment) was responsible for

\footnotetext{
${ }^{14}$ NRS, GD113/5/30b/3, A. Alexander to Gilbert Innes, 4 December 1822.

${ }^{15}$ Laura Gowing, “Giving Birth at the Magistrate’s Gate: Single Mothers in the Early Modern City,” in Women, Identities and Communities in Early Modern Europe, eds. Sue Broomhall and Stephanie Tarbin (Aldershot:
} Ashgate, 2008), 137-52.

16 Tim Hitchcock, “Begging on the Streets of Eighteenth-Century London,” Journal of British Studies 44 (2005): 478-98. 
their support during periods of poverty. ${ }^{17}$ As Snell has shown, the importance of settlement to the poor's sense of belonging was reflected in their writings, where even those who wished to avoid being returned to their parish nonetheless articulated it as their "home." ${ }^{18}$ Moreover, as Scott Mackenzie has argued, the romantic connotations of home, as not just a place of belonging but a seat of identity, that arose towards the end of the eighteenth century emerged in discourses designed for the management of the lower orders, where it was believed that it was the domesticated, moral and affective labourer's cottage that would produce an industrious and patriotic labour force. ${ }^{19}$

Yet a strong investment in "home” and "belonging” amongst the bottom rungs of society needs to be situated against an economic reality, where, as Philippa Maddern has demonstrated, many of this social group lived on the margins of society in fragile and unstable households. ${ }^{20}$ Moving from home to home and homelessness was a regular part of life for many in the lower ranks of society, disrupting ties and connections built through

\footnotetext{
${ }^{17}$ Andrew Blaikie, “Nuclear Hardship or Variant Dependency? Households and the Scottish Poor Law,” Continuity and Change 17, no. 2 (2002): 253-80; Steven Hindle, “Power, Poor Relief and Social Relations in Holland Fen, c. 1600-1800,” Historical Journal 41, no. 1 (1998): 67-96.

${ }^{18}$ K.D.M. Snell, “Belonging and Community: Understandings of 'Home’ and 'Friends' among the English Poor, 1750-1850,” Economic History Review 65, no. 1 (2012): 1-25.

${ }^{19}$ Scott R. MacKenzie, Be It Ever So Humble: Poverty, Fiction, and the Invention of the Middle-Class Home (Charlottesville: University of Virginia Press, 2013).

${ }^{20}$ Philippa Maddern, "Between Households: Children in Blended and Transitional Households in Late-Medieval England," Journal of the History of Childhood and Youth 3, no. 1 (2010): 65-86; Philippa Maddern, "Moving Households: Geographical Mobility and Serial Monogamy in England, 1350-1500,” Parergon 24, no. 2 (2007): 69-92; Philippa Maddern, “'In Myn Own House’: The Troubled Connections between Servant Marriages, LateMedieval English Household Communities and Early Modern Historiography,” in Women, Identities and Communities, eds. Broomhall and Tarbin, 45-59.
} 
geographic placement. ${ }^{21}$ As a result, household structures were also variable, with multiple families sharing a single living space, lodgers a regular feature of homelife, children and parents moving from homes to institutions and back again (and not necessarily as a family unit), and marriages and families fragmenting and being reformed in new ways. ${ }^{22}$ This is not to say, as Maddern and other show, that the poor did not create emotional ties and effective networks in these spaces, but that the fragility of their family structures destabilised such communities, requiring constant rebuilding. In this context, women, and particularly those deemed “immoral” or with illegitimate children, were particularly susceptible to marginalisation, partly because of their economic vulnerability. ${ }^{23}$ This was perhaps especially the case for women, like Hutton, from higher social backgrounds that had to form new networks amongst a social group to whom they had little to offer in terms of employment

\footnotetext{
${ }^{21}$ Sharpe and McEwan, "Introduction," 1-24; Tim Hitchcock, "Locating Beggars on the Streets of EighteenthCentury London," in Worth and Repute: Valuing Gender in Late Medieval and Early Modern Europe; Essays in
} Honour of Barbara Todd, eds. Kim Kippen and Lori Woods (Toronto: University of Toronto, 2011), 73-92; M. J. D. Roberts, "Public and Private in Early Nineteenth-Century London: the Vagrant Act of 1822 and its Enforcement,” Social History 13, no. 3 (1988): 273-94.

${ }^{22}$ Patricia Crawford, Parents of Poor Children, 1580-1800 (Oxford: Oxford University Press, 2010); Megan Doolittle, "Fatherhood and Family Shame: Masculinity, Welfare and the Workhouse in Late Nineteenth Century England,” in The Politics of Domestic Authority in Britain since 1800, eds. Lucy Delap, Ben Griffin and Abigail Willis (Basingstoke: Palgrave Macmillan, 2009), 84-110; Alysa Levene, “Children, Childhood and the Workhouse: St Marylebone, 1769-1781," London Journal 33, no. 1 (2008): 41-59; McEwan and Sharpe, "It Buys Me Freedom”; Jeremy Boulton, ““Turned into the Street with My Children Destitute of Every Thing’; The Payment of Rent and the London Poor, 1600-1850,” in Accommodating Poverty, eds. McEwan and Sharpe, 2550.

${ }^{23}$ Philippa Maddern, ““'Oppressed by Utter Poverty’: Survival Strategies for Single Mothers and their Children in Late Medieval England,” in Experiences of Poverty in Late Medieval and Early Modern England and France, ed. Anne Scott (Aldershot: Ashgate, 2012), 41-62; Gowing, “Giving Birth.” 
skills or a shared social outlook. Moreover, lower-class communities were not necessarily more forgiving of sexual immorality than their elite counterparts. ${ }^{24}$

In recent years, historians have become increasingly interested in providing access to the voices of the poor and marginal and recreating a picture of their understanding of self and their emotional lives. Yet, perhaps due to a laudable desire to recognise their agency and humanity in the wake of an older historiography that viewed the poor as emotionally unsophisticated or "hard", much of this work has focused on the positive dimensions of the emotional life of these social groups, including their strong sense of home and belonging, their ability to build close support networks, and their genuine affective ties to friends and family. ${ }^{25}$ Whilst the destabilising impact of poverty and marginality is recognised to have a detrimental impact on health, welfare, life-expectancy and political power, the "emotional toll”, the wearing away of the self and the impact on mental health, of this life has gone

\footnotetext{
${ }^{24}$ Leah Leneman and Rosalind Mitchison, Sexuality and Social Control: Scotland 1660-1780 (Oxford: Basil Blackwell, 1989); Laura Gowing, “Ordering the Body: Illegitimacy and Female Authority in SeventeenthCentury England,” in Negotiating Power in Early Modern Society: Order, Hierarchy and Subordination in
} Britain and Ireland, eds. Michael Braddick and John Walter (Cambridge: Cambridge University Press, 2001), 43-62.

${ }^{25}$ For an earlier critique of this older historiography, see: Alan Macfarlane, 'Review', History \& Theory, 18(1) (1979), pp. 103-26. For new work on the poor see: Steven King, “Friendship, Kinship and Belonging in the Letters of Urban Paupers 1800-1840,” Historical Social Research 33, no. 3 (2008): 249-77; Alysa Levene, “Poor Families, Removals and ‘Nurture’ in Late Old Poor Law London,” Continuity and Change 25, no. 2 (2010): 233-62; Joanne Bailey, “‘Think Wot a Mother Must Feel’: Parenting in English Pauper Letters,” Family \& Community History 13, no. 1 (2010): 5-19; Crawford, Parents of Poor Children; Steven King, “'I have Once More Taken the Leberty to Say as You Well Know’: The Development of Rhetoric in the Letters of the English, Welsh and Scottish Sick and Poor 1780s-1830s,” in Poverty and Sickness in Modern Europe: Narratives of the Sick Poor, 1780-1938, eds. Andreas Gestrich, Elizabeth Hurren and Steven King (London: Continuum, 2012), 69-91. 
uncovered, perhaps partly due to a wish to avoid repeating tropes of the poor as emotionally diminished.

The emotional toll of marginality for Innes’ mistresses was shaped by the urban context in which they lived and articulated in spatial terms. The role that "space," incorporating not only landscape and architecture but the social and cultural investments that give those physical contexts meanings, play in shaping behaviour, including affective action and emotion, is increasingly recognised. ${ }^{26}$ Doreen Massey has noted the way that domesticity became a spatial control on women's movements, whilst the constraints on women's use of the city due to the gendering of both urban space and human bodies are well recognised. ${ }^{27}$ Similarly, particular spaces, such as the home, carry affective connotations that impact on its inhabitants, their activities and their emotional lives, and in turn, people's use of household space signalled their emotions to others. ${ }^{28}$ As this chapter explores, for Hutton, the mobility and transience of life of a mistress was not only physically wearing but came to signify her social marginality and dislocation from middle-class life, shaping her emotional wellbeing. In

\footnotetext{
${ }^{26}$ Erica Carter, James Donald and Judith Squires, eds., Space and Place: Theories of Identity and Location (London: Lawrence \& Wishart, 1994); Amanda Flather, Gender and Space in Early Modern England (Rochester: Boydell and Brewer, 2007); Susan Bordo, Binnie Klein and Marilyn K. Silverman, "Missing Kitchens,” in Places Through the Body, eds. Heidi Nast and Steve Pile (London: Routledge, 1998), 72-92. ${ }^{27}$ Doreen Massey, Space, Place and Gender (Cambridge: Polity Press, 1994), 179-80; Daphne Spain, “Gendered Spaces and Women's Status,” Sociological Theory 11, no. 2 (1993): 137-51; Elizabeth Munson, "Walking on the Periphery: Gender and the Discourse of Modernization," Journal of Social History 36, no. 1 (2002): 63-75; Anu Korhonen, “To See and to be Seen: Beauty in the Early Modern London Street,” Journal of Early Modern History 12 (2008): 335-60.

${ }^{28}$ Donna Birdwell-Pheasant, “The Home 'Place’: Center and Periphery in Irish House and Family Systems,” in House Life: Space, Place and Family in Europe, eds. Donna Birdwell-Pheasant and Denise Lawrence-Zúñiga (Oxford: Berg, 1999), 105-32; Katie Barclay, "Place and Power in Irish Farms at the End of the Nineteenth Century,” Women’s History Review 21, no. 4 (2012): 571-88.
} 
contrast, she understood "a home” as stable and unmoving that gave a person a "place” within her community and so an identity and emotional health. For Hutton, space, affect and sociability were inextricably linked, with the "home" acting to embed her in a community of peers.

In the absence of a stable household and as I explore at length elsewhere, Hutton used the letter to create a home with Gilbert, locating him in the gendered role of "husband" and provider. ${ }^{29}$ The letter became an affective space that enabled sociability over distance, imaginatively constructing the emotional dimensions of homelife through writing that focused on the intimate, the domestic and its place within the community. Yet, whilst the letter was a crucial to sociability for the polite, Innes alone was not able to provide the community and place that Hutton, and his other mistresses, required to be at home within Edinburgh. For women like Hutton, home was not simply about emotional connection within the nuclear family or with a spouse, but about being embedded within a local and known community, one which provided the sustenance of friendship and support and reinforced a person's sense of self through acknowledgement of their status and role in the community. In this, sociability within a wider community of family, friends and neighbours was essential to a person's emotional wellbeing and selfhood, weaving together family, community, social status, and household into personal identity.

\section{Social and Affective Marginality in Enlightenment Edinburgh}

Enlightenment Edinburgh, like many British cities of the period, was a site of contradictions. It was known for its moral conservatism at all social levels throughout the eighteenth century, in a context where the Kirk remained politically powerful and the social authority of the Scottish elite rested on their "polite" identities, for which sexual propriety was central. ${ }^{30}$ Yet,

\footnotetext{
${ }^{29}$ Barclay, "Illicit Intimacies”.

${ }^{30}$ Mitchison and Leneman, Sexuality and Social Control; Katherine Glover, Elite Women and Polite Society in Eighteenth-Century Scotland (Woodbridge: Boydell and Brewer, 2011). Katie Barclay, "Sex, Identity and
} 
especially after the mid-century when the population expanded and the policing of moral behaviour by the Kirk became more difficult, it was also a city with a growing number of prostitutes and a market for those prostitutes, whilst the location of the divorce court encouraged unhappily married couples to remove there from across the United Kingdom to pursue marital separation, usually on the grounds of infidelity. ${ }^{31}$ The increasing anonymity available to its inhabitants also made it a popular location for unwed mothers to come to give birth, and for them and other marginal people to remake their lives. ${ }^{32}$ Yet, while historians have a sense of the growing anonymity of the city and its uses by the eighteenth-century Scottish population, just how "anonymous” it was and the impact on the lives of the marginal has been difficult to uncover. Mary Hutton's letters provide unique access into the daily lives of women in this context.

Like any letter, Hutton's writings to Innes are mediated texts shaped by the two-way nature of the conversation, as well as by Hutton's need to present a particular self to Innes. ${ }^{33}$ Hutton relied on Innes for her income - an income that was irregular and often related to her making a case of compelling “need,” rather than a set allowance. As Innes’ affection waned

Enlightenment in the Long Eighteenth Century," in Shaping Scottish Identity: Family, Nation and the World Beyond, eds. Jodi Campbell, Elizabeth Ewan and Heather Parker (Guelph: Guelph University Press, 2011), 2942.

${ }^{31}$ Rosalind Carr, Gender and Enlightenment Culture in Eighteenth-Century Scotland (Edinburgh: Edinburgh University Press, 2014); Gillian Beattie-Smith, "Writing the Self: The Journal of Sarah Stoddart Hazlitt, 17741843,” Women’s History Review 22, no. 2 (2013): 197-210.

${ }^{32}$ Katie Barclay, “Gossip, Intimacy and the Early Modern Scottish Household,” in Fama and Her Sisters: Gossip in Early Modern Europe, eds. Claire Walker, Heather Kerr, and Helen Payne (Turnhout: Brepols, 2014); Rab Houston, Social Change in the Age of Enlightenment: Edinburgh, 1660-1760 (Oxford: Oxford University Press, 1994).

${ }^{33}$ For an extended discussion of letters as mediated texts see: Katie Barclay, Love, Intimacy and Power: Marriage and Patriarchy in Scotland, 1650-1850 (Manchester: Manchester University Press, 2011), 26-31. 
as their relationship aged, meaning that he visited less often, provided less money and failed in the small affectionate remembrances (such as sending the newspaper) that had marked their early relationship, money and material circumstances were often a central theme within her writing. Building a "home” in writing and locating Innes in the traditional role of “provider” was a central way that Hutton maintained her relationship with him, using the letter as an affective space that sat imaginatively in place of the home she craved. ${ }^{34}$

Hutton had important reasons to emphasise her economic vulnerability and marginality that did not necessarily arise strictly from an exact accounting of her circumstances. Innes appears to have felt that Hutton exaggerated her poverty and her social marginality, and she spent considerable time providing evidence of her "truthfulness," including detailed accounting of her expenditure and events in her life. However, in many respects Innes' scepticism can also be viewed as a convenient reading of Hutton's letters, freeing him from guilt over his actions or his responsibility for her social positioning. Certainly, emphasising his responsibility for her social marginality - her dislocation from friends and family - seemed to be an effective rhetorical device for Hutton, in that it was often followed by him sending money. Rather than seeing Hutton’s writing as cynical however, it is probably more helpful to understand them as her subjective response to the social marginality that she spent considerable time describing to Innes. Whilst her letters were designed to create sympathy or pity in her reader, they were also an attempt to share her life and feelings with her lover over distance - she desired him to pity her due to her circumstances, because culturally and for both Hutton and Innes that was the appropriate emotion that a lover would show. It also allowed her to present herself as a middle-class and respectable woman, showing her sensibility to her reduced circumstances and reinforcing her sense of self.

\footnotetext{
${ }^{34}$ Barclay, "Illicit Intimacies.”
} 
When Mary Hutton met Innes she was living in central Edinburgh, probably in the New Town near St Andrew’s Church and Innes’ home on St Andrew’s Square. Whether she was living at home or as a governess is unknown, but it appears to be the area where her family lived and in which she was well known. The details of how her relationship with Innes became known are also unclear, but in 1818, when she was staying with a family friend, Mrs Mackintosh, near to Innes' home, Hutton was put out of the house. ${ }^{35}$ A year later, when she had once more been asked to move lodgings and was unable to find new ones, she wrote of the trauma of that experience noting: "My trunk must be removed tomorrow morning, I know not what to do. I dare not go to lodgings, surely you pity me my dear Monsieur for I feel the same kind of horror that I did last year when Miss McIntosh put me out.”36 The threat of homelessness was a recurrent theme within her letters, where "homeless” was used as an emotive signifier designed to stir emotion in Innes. “Ah do you not pity poor Homeless Mdriven about like a pair of old Boots - hard fate,” she asked after being put out of her accommodation. ${ }^{37}$ In the same situation a few years later, she sighed, “O! Monsieur, the homeless wretch only can know what my feelings are.” ${ }^{38}$ For Hutton, homelessness was not only terrible, creating "horror" in the homeless and demanding "pity" from the external observer, but incomparable to other painful situations.

After she was put out of Mrs Mackintosh’s house, Hutton both felt and was compelled by circumstances to leave the New Town. One of her reasons for avoiding this area was a strong sense that her exposure had shamed her family and she was very reluctant to return and cause them further harm. This was a recurrent concern in her writing, suggestive of a

\footnotetext{
${ }^{35}$ NRS, GD113/5/471/41, MP to Gilbert Innes, 11 August 1818.

${ }^{36}$ NRS, GD113/5/474/6, MP to Gilbert Innes, 25 August 1819.

${ }^{37}$ NRS, GD113/5/474/155, MP to Gilbert Innes, 23 May 1819.

${ }^{38}$ NRS, GD113/5/484/99, MP to Gilbert Innes, 21 May 1823.
} 
continued hope that one day she would be reconciled to her family as well as her difficulty imagining her "self” beyond her family identity. ${ }^{39}$ Yet there was also the practical consideration that Edinburgh's respectable lodging-housekeepers would not lease their rooms to her or would remove her once they learned of her reputation. As she noted:

a bad report has certainly gone out against me, from what I can learn nothing but moving so often from House to House is fixed upon against me, but that is sufficient to make people decline my acquaintance and at the same time watch my motions, if I could hope things would mend but I can have no such hope, the report will spread wider and wider, and the consequences more and more fatal. ${ }^{40}$

The "fatal consequences" that Hutton alluded to were not just the physical and moral risks that homelessness entailed, but a reduction of her sensibility. She continued in the same letter: "see what a sad heart I have - I feel it still swelled as if it would break asunder - but not one tear falls to release it." ${ }^{41}$ Hutton's inability to express her emotion in tears represented a lessening of her sensibility caused by the difficult circumstances that she lived under. In this, she drew on wider social ideas about both the ways that a life of sexual immorality "hardened" the seduced women, who became increasingly depraved until the "fatal consequence" of losing both humanity and salvation, and on some of the more positive imaginings of the emotional lives of the poor, that located their (seeming) lack of sensibility in their social circumstances. ${ }^{42}$ For Hutton, “homelessness” signified not just insecurity and

\footnotetext{
${ }^{39}$ NRS, GD113/5/484/10, MP to Gilbert Innes, 6 April 1823; GD113/5/485/133, MP to Gilbert Innes, 31

December 1823.

${ }^{40}$ NRS, GD113/5/474/7, MP to Gilbert Innes, 28 August 1819.

${ }^{41}$ Ibid.

${ }^{42}$ Katherine Binhammer, The Seduction Narrative in Britain, 1747-1800 (Cambridge: Cambridge University Press, 2009); MacKenzie, Be It Ever So Humble.
} 
poverty, but a loss of emotional personhood that was vested in home's association with family, community, status and place.

In the following years, the constant threat of homelessness lingered due to her considerable transience. From the New Town, Hutton moved outwards to other areas of Edinburgh and ultimately to Portobello, now a suburb of Edinburgh but at that time a port town and popular beach holiday destination four miles away. Whilst she spent most of the year in Portobello, she never settled there constantly. Instead, she moved back to Edinburgh, or to Glasgow, and on at least a couple of occasions, to Liverpool. Occasionally, she made visits, like others of her social class, to wider, often lower middling-class, relatives further afield in Scotland, who either did not know her reputation or were less concerned about it. ${ }^{43}$ Hutton moved frequently. In 1824, she told Innes that she had stayed with sixty-five "families" since they had met, and listed the fifteen households in which she had lived in the last year. ${ }^{44 ~ " F a m i l y " ~ h e r e ~ s i m p l y ~ m e a n t ~ " h o u s e h o l d ", ~ r e f e r r i n g ~ t o ~ a ~ v a r i e t y ~ o f ~ t y p e s ~ o f ~}$ lodging from short-term stays in inns to longer-term room lets that included board, to stays with biological relations. Yet, her use of "family", a conventional expression during the period, flags the emotional implications of "home”. Where one lived was never, and could not be, simply a place to lie one’s head; rather, even short-term paying visitors were imaginatively and emotionally embedded into the family-household, tying them into a network of relationships that were expected to deepen over time. ${ }^{45}$

Hutton’s transience was partly a result of her relationship with Innes becoming known to her lodging-housekeepers, but was also influenced by her income. Portobello’s

\footnotetext{
${ }^{43}$ NRS, GD113/5/491/24, MP to Gilbert Innes, 12 April 1825.

${ }^{44}$ NRS, GD113/5/488/48, MP to Gilbert Innes, 1 August 1824; GD113/5/486/133, MP to Gilbert Innes, 5 March 1824; GD113/5/486/140, MP to Gilbert Innes, 11 March 1824.

${ }^{45}$ Naomi Tadmor, Family and Friends in Eighteenth-Century England: Household, Kinship and Patronage, (Cambridge: Cambridge Univeristy Press, 2001).
} 
accommodation prices went up during the summer when there were lots of tourists, forcing Hutton to move houses. ${ }^{46}$ Many other landladies were only willing to rent to her for short periods, often between longer-term and better paying clients. ${ }^{47}$ Hutton, however, also felt compelled to move because she believed that "Living in a Lodging House without any character, and no Friends to acknowledge or protect me, entirely precludes all hope of being respected.”48 She appeared to believe that moving regularly between different towns and cities provided a respectable explanation for never taking longer-term accommodation, maintaining this image through lying to her landlords about where she was going next. ${ }^{49}$ For Hutton, perhaps ironically given her desire for a home, moving regularly ensured her reputation by limiting how embedded she became within the communities she stayed in, and so ensured her privacy from nosey neighbours. Yet, in maintaining shallow ties, Hutton could never establish the reputation or community she craved.

Getting respectable lodgings as a woman without a character, both written (from previous landlords) and in a moral sense, was difficult. As a middle-class woman who wished to preserve a semblance of respectability, Hutton felt compelled to take lodgings in a "higher” level of accommodation, tying standard of housing and social class tightly together. This decision was motivated by a number of interlocking beliefs: that she was middle-class and needed to maintain an appearance of class to shore up her reputation; that she needed to maintain her reputation for the benefit of her wider family's reputation and also for Innes’ sake so that he could visit her without too much wider commentary; and that "low" lodgings

\footnotetext{
${ }^{46}$ NRS, GD113/5/488/39, MP to Gilbert Innes, 28 July 1824.

${ }^{47}$ NRS, GD113/5/30C/5MP to Gilbert Innes, 26 March 1821; GD113/5/30C/8, MP to Gilbert Innes, 13 October 1822; GD113/5/490/3, MP to Gilbert Innes, 4 January 1825; GD113/5/488/68, MP to Gilbert Innes, 12 August 1824; GD113/5/485/52, MP To Gilbert Innes, 12 November 1823.

${ }^{48}$ NRS, GD113/5/486/134, MP to Gilbert Innes, 6 March 1824.

${ }^{49}$ NRS, GD113/5/30C/2, MP to Gilbert Innes, 20 May 1820.
} 
did not provide the sociability that a woman of her "polite” pedigree was used to and required. ${ }^{50}$ But it was also informed by a strong sense that to lose her "respectability" was to lose an essential dimension of her selfhood, hastening a loss of sensibility that marked both her inner emotional life and her social class. ${ }^{51}$

Respectable lodgings maintained their reputations as "higher" levels of accommodation through enforcing a strict moral code; many avoided taking single women altogether as the risk was deemed too high: "I have been to twenty different Lodging Houses this last week but the general answer I get is that they do not take in females." ${ }^{52}$ Almost all the lodgings Hutton stayed in were managed by female housekeepers (although many had husbands) and they needed to maintain a strict moral code for the sake of their own reputations, as well as that of their business. ${ }^{53}$ Hutton herself recognised this and occasionally felt remorse at the potential damage she did to them: "See me living in a mean apartment in a common Lodging House without a single acquaintance to visit. Would those 28 families in Edinburgh who must abhor my very name from feeling that my living in their houses have left an indelible stain upon them. Would they not be nearly satisfied.” ${ }^{54}$ On one occasion, she lodged with a "black man,” who may similarly have needed to enforce strict moral codes to maintain business. ${ }^{55}$

Before being given lodgings, Hutton was often subjected to close questioning: “I may go in to 20 different houses where they will ask a great many questions, and after all not take

\footnotetext{
${ }^{50}$ NRS, GD113/5/484/10; GD113/5/484/16, MP to Gilbert Innes, 2 April 1823.

${ }^{51}$ Randall McGowen, “A Powerful Sympathy: Terror, the Prison and Humanitarian Reform in Early Nineteenth-Century Britain,” Journal of British Studies 25, no. 3 (1986): 312-34.

52 NRS, GD113/5/30C/2.

${ }^{53}$ McEwan and Sharpe, "Genteel Lodging."

${ }^{54}$ NRS, GD113/5/30C/1, MP to Gilbert Innes, 8 May 1820.

${ }^{55}$ NRS, GD113/5/485/117, MP to Gilbert Innes, [21 December 1823].
} 
me.”56 On one occasion, she used “lodging house ladies,” women who organised accommodation for strangers, to find her a place in Glasgow, but found them particularly nosey: "when they get a stranger in their power they delight in giving them trouble before they get lodgings for them. I have never seen that spirit more clearly manifested then at this time." ${ }^{57}$ Many lodging-housekeepers required Hutton to promise that she would not have male visitors, whilst she often felt that she had little privacy, her movements constantly observed. ${ }^{58}$ She described Portobello as "so watchful and so deeply attached that I look forward to much difficulty in getting from there without exciting suspicion." ${ }^{59}$ With "deeply attached," the sense of the local community as one that embedded the early nineteenthcentury individual within it, creating ties of neighbourly affect whilst policing the boundaries of its membership comes once more to the fore. Innes suggested that the extent of watchfulness in the neighbourhood was her imagination (telling given his own anxieties around being seen), but she argued that as she was "genteel” more people had an eye on her and she had greater responsibility than a "low born woman." 60 Some people were willing to report her behaviour. In 1823, a notice about her was posted on the door of her winter lodgings, which deeply upset the owner who a year later was still in "a great rage that her family had been looked down upon for keeping me." 61

Such a lack of privacy was especially difficult for a woman whose income was reliant on her socially-illicit relationship, but as Amanda Vickery notes, even more generally privacy was important to a person's sense of self during the period, where "Life with no vestiges of

\footnotetext{
${ }^{56}$ NRS, GD113/5/485/82, MP to Gilbert Innes, 29 November 1823.

${ }^{57}$ NRS, GD113/5/491/6, MP to Gilbert Innes, 31 March 1825.

${ }^{58}$ NRS, GD113/5/485/84, MP to Gilbert Innes, 2 December 1823.

${ }^{59}$ NRS, GD113/5/488/136, MP to Gilbert Innes, 5 October 1824.

${ }^{60}$ NRS, GD113/4/484/42, MP to Gilbert Innes, 24 April 1823.

${ }^{61}$ NRS, GD113/5/488/23, MP to Gilbert Innes, [16 Jul 1824].
} 
privacy was understood to be a most sorry degradation which stripped away the defences of the spirit." ${ }^{2}$ Hutton emphasised the "wear and tear" that this lack of privacy took upon her body, noting "My feelings are undoubtedly much subdued but my constitution is too much shaken to be trifled with, my nerves are unhinged for ever. Two years suffering has left me a real object in that respect. I have to watch and regulate my very thoughts to keep away the ague because it wastes me so much both in Mind and Body.",63

The emotional toll of this lifestyle had a physical impact on the body, something exasperated by the transient nature of her lifestyle. Many of her letters describe not only the frustration and monotony of looking for new accommodation, but its physical effects: "I am sure I was in 20 different rooms which were unoccupied, and saw many different Characters. ... I had mounted stairs till my limbs seemed breaking under me, and fell quite worn out.” 64 Such descriptions were pervasive throughout Hutton's writings and she clearly expected Innes to sympathise with the labour and energy that she depleted. It was also a situation exasperated by the expense of living in short-term lodgings and inns that, on occasion, meant that she went without food:

I payed for four nights lodging \& my breakfast four times, which came to $12 / \&$ a shilling for cleaning my shoes but had I taken dinner, tea and supper I would have had a very different [illegible - amount?] to pay. I left the Inn always about 11 oclock \& wandered about the town \& rested myself in shops upon a glass of whisky \& some gingerbread till 10 oclock at night when I returned to the Inn to my Bed. ${ }^{65}$

\footnotetext{
${ }^{62}$ Amanda Vickery, “'An Englishman’s Home is his Castle?’ Thresholds, Boundaries and Privacies in the Eighteenth-Century London House,” Past and Present 199 (2008): 151.

${ }^{63}$ NRS, GD113/5/30C/7, MP to Gilbert Innes, 1 September 1822.

${ }^{64}$ NRS, GD113/5/485/84.

${ }^{65}$ NRS, GD113/5/491/16, MP to Gilbert Innes, 7 April 1825.
} 
Staying in Inns was not only expensive, but often required Hutton to be absent all day. Sometimes this appears to be due to the multiple uses of space in an Inn and that her rent only covered her during the evening, but on other occasions, it was a strategy for avoiding explanations about refusing meals; it appeared more respectable to be "eating elsewhere" than not at all. ${ }^{66}$ This was a risky strategy for a single woman. In Liverpool, she noted that "I walk about 2 hours every day which is as much as I am able for or could do without being suspected [as a prostitute].” ${ }^{67}$ And, on at least one occasion, she was approached by a man with that view in end. ${ }^{68}$

The culmination of her experience was exhaustion, as she noted to Innes: "I had to live at the Inn till yesterday... I wandered the rest of the time about this filthy town, always till 10 Oclock at night when I went to bed, what with anxiety \& fatigue \& want of food \& shame from appearing so destitute, I am worn out to a degree that you can hardly conceive.” ${ }^{99}$ In this, the physical toll on the body of hunger and being outside merged with the emotional toll, “anxiety” and "shame,” draining her of energy and ultimately happiness. Transience and marginality was not just marked by a spatial distancing from respectable society, but in its wearing at the self and the emotional health of the marginal.

\section{"A Home and Quietness is all my Ambition"70}

In contrast, "a home” represented everything that was missing from this life: security, health, respectability, sociability, affection and a secure place in the community. The years 1823-24 were particularly difficult for Hutton, as she was put out of lodgings several times, and finally resorted to renting a house that she could not afford, begging Innes to pay. Innes paid the

\footnotetext{
${ }^{66}$ McEwan and Sharpe, “Genteel Lodging,” 147-48.

${ }^{67}$ NRS, GD113/5/30C/2.

${ }^{68}$ NRS, GD113/5/485/84.

${ }^{69}$ NRS, GD113/5/486/50, MP to Gilbert Innes, 7 February 1824.

${ }^{70}$ NRS, GD113/5/486/34, MP to Gilbert Innes, 28 January 1824.
} 
balance, but made her give it up at the end of her let. This was immensely frustrating for Hutton, who explained to Innes that "people wonder and suspect me of wrong if living in a lodging house, but appeared something like myself when in a house of my own and a decent servant with me.”71 Living in her own house brought Hutton to "something like herself,” explicitly tying the experience of home “ownership” to a rebuilding of selfhood and affective life that was being worn away for the "homeless vagabond.” Ultimately, Hutton’s lack of a home came to represent her marginality socially and emotionally:

O Fie Monsieur to give an affectionate and tried friend of nearly 11 years standing, the despicable name of chere amie a name which belongs to the lowest $\&$ most worthless of women, in truth I have no right to the term[.] Chere Amies are much beloved, are allowed a home, and other privileges that a wandering whore such as you have kept me know nothing about. $^{72}$

Innes' refusal to provide a “home”, as Hutton defined it, marked his lack of affection, and her “marginal” place in his life, as well as her dislocation as a "wandering whore” within wider society. She reinforces this point through her use of "Chere Amie”, a popular nineteenthcentury colloquialism for a mistress, usually signifying a woman supported by a lover who had exclusive sexual access to her, and by pointing out that she was not even accorded the benefits of a typical women in that lowly position. ${ }^{73}$

A home allowed Hutton to be a full member of society; its loss signified not only isolation but a separation from her social class:

It is not the trouble of going from House to House that I regret, nor is it the many disagreeable things I meet with, nor the almost perpetual solitude I live in, all that I richly deserve by

\footnotetext{
${ }^{71}$ NRS, GD113/5/487/69, MP to Gilbert Innes, 20 May 1824.

${ }^{72}$ NRS, GD113/5/488/137, MP to Gilbert Innes, 6 October 1824.

73 The journalist Henry Mayhew, for example, uses Chere Amie for a particular class of high-end prostitute: London Labour and the London Poor (London: Griffin, Bohn, and Company, Stationers’ Hall Court. 1862).
} 
straying from the path of virtue I was brought up in, but my broken heart longs for the respect that my Father's daughter and my former conduct entitled me to. ${ }^{74}$

Hutton thought it was "impossible for one at my time of life without a home and without a friend to keep a good character," and that "My very destitute situation requires the utmost caution and forbearance on my part to make it appear at all respectable.”75 This was a situation exasperated by her lack of access to people from her own social group and that she was required to rely on conversation with "low people who are worse than none to me having never been used to them."76 As "home” was so integrally tied to Hutton’s sense of personhood, she required a physical homespace that reaffirmed her sense of herself as a middle class, respectable woman.

Yet the social dislocation caused by a "lack of home" was not unique to Hutton. A. Alexander was far less transient, living most of her life in or around the Canongate in Edinburgh. But she experienced the same sense of dislocation from friends, family and neighbours, telling Innes that his visits: "enable me to bear the calumney and persecutions for your sake as an outcast from society and a lonley and a forlorn being” reducing the sense that "my life is a burden to me."77 She also asked for a home on several occasions, arguing it would be a sign of his generosity and make her less of a burden upon him. ${ }^{78}$ As she aged, a home also came to represent a safety net: "the security that I would be taken care of till I die" and "esentell to my happiness."79 Alexander based her desire for a home on the more pragmatic concerns of economic prudence and security for when she could no longer work,

\footnotetext{
${ }^{74}$ NRS, GD113/5/486/134.

${ }^{75}$ NRS, GD113/5/30C/2; GD113/5/474/155.

${ }^{76}$ NRS, GD113/5/30C/5.

${ }^{77}$ NRS, GD113/5/486/106, A. Alexander to Gilbert Innes, 29 March 1824.

${ }^{78}$ NRS, GD113/5/481/47, A. Alexander to Gilbert Innes, [12 March 1822].

${ }^{79}$ NRS, GD113/5/490/29, Anonymous [A. Alexander] to Gilbert Innes, [20 January 1825].
} 
but similarly to Hutton, it was tied into a wider discourse of being part of society and a caring, both affective and practical, network, contrasted explicitly with having "none other to take care of me.” ${ }^{80}$ For these women, a home not only symbolised a woman’s place in society, but acted to establish that place, counterbalancing the impact of marginality, social, financial and affective, at multiple levels.

Whilst growing in size, anonymity was not available to everyone in Edinburgh and it was quickly counterbalanced by the policing of new incoming members by the wider community, as well as gossip networks that stretched beyond the borders of particular neighbourhoods. As a result, people, but particularly women for whom sexual reputation was vital, had to work hard to present themselves as respectable in order to forge and maintain their place. What respectability entailed was shaped by social class, with differing expectations for dress, accommodation, food consumption, and behaviour being applied to women from different social backgrounds, but across all social groups sexual probity was viewed as vital (although the social consequences of not conforming differed across gender, class and circumstance). Women who could or would not conform to such expectations were frequently socially marginalised, often left isolated from family, friends and support networks, and occasionally pushed into a transient lifestyle as they were forced or encouraged to "move on."

As is well recognised, such marginality often had real consequences for wealth, physical health, life expectancy, and political power, but it also had an impact on people’s emotional wellbeing. Living on the margins of society wore away at a person's sense of self, perhaps exasperated in a context where "friends" and community were still vital to how people understood their sense of identity and for their affective connotations of place and

\footnotetext{
${ }^{80}$ Ibid.
} 
Marginal Households 26

embedded sociability. ${ }^{81}$ Hutton felt marginality as a hardening of her sensibility, an inability to fully mourn her circumstances, but also as a heightening of her nerves and levels of anxiety. It was accompanied by a strong sense of isolation and shame, and both Alexander and Hutton expressed a willingness to die or weariness with life. ${ }^{82}$ Despite this, Hutton clearly worked very hard to present herself as respectable, demonstrating a tenacity and desire to remain part of society despite the toll a marginal life placed upon her physically and emotionally. In this, "the home," an imaginary and emotive construct, became the location of women like Hutton's hopes and dreams, a place that would take them from the edges of society to full members of the community that determined your sense of self, and, with it, bring healing to both body and mind. Whilst she enacted a "home" imaginatively with Innes, using their correspondence as a affective space to create love and a sense of family, letters were unable to provide the level of sociability of the physical home, which tied a person into an “attached” community, one that was “watchful” but in watching reinforced a person’s respectability and membership of a "caring” community. For these women, space and place not only marked a person's relationship to society, but was deeply connected to emotional health and sense of self.

\footnotetext{
${ }^{81}$ Naomi Tadmor, Family and Friends in Eighteenth-Century England: Household, Kinship and Patronage (Cambridge; Cambridge University Press, 2001).

${ }^{82}$ NRS, GD113/5/482/69, A. Alexander to Gilbert Innes, [17 May 1822]; GD113/5/484/9, MP to Gilbert Innes, 5 April 1823.
} 